\title{
Environmental policy and climate change vulnerability in the Maldives: from the 'lexicon of risk' to social response to change
}

\section{Stefano Malatesta}

University of Milano-Bicocca, Italy, Republic of the Maldives

stefano.malatesta@unimib.it

\section{Marcella Schmidt di Friedberg}

University of Milano-Bicocca, Italy, Republic of the Maldives

marcella.schmidt@unimib.it

\begin{abstract}
The climate change vulnerability discourse in the Maldives coexists with a pervasive set of critical environmental factors of significance to the socio-environmental systems of small peripheral islands. This implies the need to strike a balance between global challenges associated with environmental processes at the supra-national scale and the adjustments and strategies implemented at the local scale in response to change. The current paper offers a discussion of this dialectic, in reference to both the broader contemporary debate in island studies, and the political and environmental context of the Maldives. We first outline the international scenario, and then go on, in the second part of the paper, to provide a reading of environmental policy on these islands. We argue that emphasizing the country's environmental vulnerability has reinforced a 'lexicon of risk' within the environmental discourse and that, in recent years, this narrative has been one of the main forces driving the construction of contemporary Maldivian 'nation-ness'.
\end{abstract}

Keywords: climate change vulnerability, environmental policy, islands, lexicon of risk, Maldives

https://doi.org/10.24043/isj.5

(C) 2017 - Institute of Island Studies, University of Prince Edward Island, Canada.

\section{Introduction: frameworks and dialectics}

Over the past four years, we have carried out extensive field work across the Maldives, interviewing environmental activists, tour operators, administrators, and representatives of local institutions. As environmental geographers, we set out to analyze both environmental policies and the production of narratives about the country's environmental vulnerability. However, our meetings with local actors prompted us to explore the dialectics underlying these policies and narratives.

This paper aims to integrate discussion of these dialectics with an understanding of the environmental challenges at the local scale, both in relation to the contemporary debate in island studies (Hay, 2006; Baldacchino, 2008; Baldacchino \& Niles, 2011; Stratford et al., 2011; Taglioni, 2011), and in light of the political and environmental milieu of the Maldives. We mainly draw on two theoretical references: political ecology and the study of social responses to environmental changes. We outline key aspects of the regional context, before gradually honing in on, and proposing a reading of, Maldivian environmental policies. We conclude by taking a closer look at local socioenvironmental systems, suggesting that focusing on the local scale may offer a promising path for policy-makers and researchers. In general, we attempt to show that, in the context of the country's environmental policies, constant reference to the Climate Change Adaptation (CCA) framework (Birkmann \& von Teichman, 2010) has had the effect of consolidating a 'lexicon of risk' in environmental discourse, and that, in recent years, this has become one of the main forces driving the construction of contemporary Maldivian 'nation-ness' (Anderson, 1983). 
In this paper, we define the 'lexicon of risk' as a narrative based on three elements: the dominant influence of the CCA framework on environmental legislation and planning; a focus on the national and supra-national scales; and the notion of 'vulnerability' as a key element in the ongoing construction of the country's geographical imaginary.

The discourse on the Maldives' environmental vulnerability-built around the current emphasis on global environmental threats such as climate change (Gay, 2014) -coexists, on the inhabited islands, with a set of critical environmental processes pervading local communities. At the political level, this dialectic is reflected in the tension between the primacy of the CCA framework, and the quest for actions, tools, and projects to enhance the practices and knowledge of local human systems. It may also be identified in the need to find a synergy between measures taken to address environmental challenges at the supra-national scale and the adjustments and strategies implemented by socio-environmental systems at the local scale. The emergence of these dialectics confirms the principle that, in our field of study, researchers should seek to shed light on the "political sources, conditions and ramifications of environmental change" (Bryant, 1992, p. 12). In other words, scholarly readings of environmental policies should be informed by an understanding of so-called 'political ecologies'. The achievement of political ecology as an interdisciplinary field-whose main object of analysis is the power relations underlying socio-environmental processes and environmental discourse (Bryant, 1992; Bryant \& Bailey, 1997; Pelling, 1999; Adger et al., 2001) —has been linked to the awareness that "political processes and institutions are rarely mentioned directly and even more rarely analysed in detail" (Deutsch, 1977, p. 359), and that "environmental problems assume greater political significance, [therefore] the need for an analytical approach integrating environmental and political understanding becomes more pressing" (Bryant, 1992, p. 12). Furthermore, in island studies, this approach has been employed to discuss the construct of small island vulnerability (Pelling \& Uitto, 2001; Kelman, 2010, 2014) and analyze the socio-political implications of climate change in the Maldives (Kothari, 2014).

As geographers, we recognize the importance of applying a trans-scale reading (Kates \& Wilbanks, 2003) to the environmental challenges and changes facing the Maldives, given the interdependence between environmental priorities at the national level, as reflected in the recent legislation discussed in this paper, and the transformative forces impacting on the smaller, more peripheral islands. In addressing these topics in the second part of this paper, we use the concept of 'social response to change'. Building on the legacy of the 'human ecology' paradigm (Kates, 1971), the study of social response focuses on the body of practices, adjustments, knowledge, and technology that communities develop (and adopt) to cope with environmental change. The aim of this approach is to "discern interactions between social practices, values and change" (Adger et al., 2013, p. 112) shaping socio-environmental systems at the local scale. Such an emphasis on the complex set of strategies developed by human communities, here defined as 'social response', directly speaks to the broader debate about adaptation and resilience of local systems (O'Riordan \& Jordan, 1999; Pelling \& Uitto, 2001; Kates \& Wilbanks, 2003; Adger et al., 2009; Pelling, 2011; Adger et al., 2013; Kelman, 2014).

In relation to the epistemological bases of our work, one of the most significant features of this debate has been the discussion of the key role played by institutional and social drivers in strategies and policies of adaptation and resilience. In particular, Adger et al. (2009) draw on 'cultural theory' (Thompson et al., 1990; O'Riordan \& Jordan, 1999), proposing a 'social reading' that integrates the four dimensions most frequently associated with adaptation mechanisms: ecological, physical, economic, and technological. According to these authors, the limits to adaptation at the local scale "are endogenous and emerge from 'inside' society [...] It all depends on goals, values, risk and social choice. These limits to adaptation are mutable, subjective and socially constructed" (Adger et al., 2009, p. 338). In light of our own focus here, this perspective should be accompanied by the awareness, as stated by Kelman (2014, p. 121), that island communities "have a long history of addressing social and environmental challenges [...] that could apply to dealing with climate change." 
The present study is part of the broader research programme being conducted by the Marine Research and High Education Center (MaRHE) on adjustments to environmental changes in the Maldives. It is based on a review of the relevant literature as well as on a content analysis of laws, programs, and reports. Our focus on the narratives associated with existing national legislation has been inspired, in particular, by the recent works of Sovacool (2012) and Kothari (2014) on Maldivian environmental policies. The list of laws, programs, and reports chosen for analysis were selected following three criteria: the legislative activity of the Ministry of Environment over the last three presidencies; explicit references, within the texts, to the CCA framework; and the indications provided by 25 informants interviewed as part of our fieldwork. ${ }^{1}$

\section{Scales and geographies}

The human geography of the Maldives is characterized by the spatial antithesis between concentration and dispersion (Malatesta et al., 2014), and by centre/periphery relations and imbalances (Reynaud, 1984). Such spatial patterns act, and interact, within the geography of the archipelago, in relation to population distribution, capital accumulation, resource management, and accessibility to services. They are borne out by the most recent census data on how the population is distributed over the 191 inhabited islands, 189 islands, and two cities (National Bureau of Statistics, 2014). In fact, about 39\% of the population lives in Male (the capital island), which, with a surface area of under 200 hectares, is home to 153,000 people. The remaining $61 \%$ of the population, amounting to about 240,000 inhabitants, is spread among atolls with small populations (between 1,000 and 4,500 inhabitants) and a low number of inhabited islands and atolls with over 15,000 inhabitants. ${ }^{2}$

These spatial trends are even more evident if one considers that the two least-inhabited atolls (Faaf and Felidhoo), with only 10 inhabited islands each, are located in the central region, less than 80 nautical miles from the capital (and therefore relatively close to the country's economic, demographic, and political core), while the two most-populated atolls (Seenu and Haa, respectively the southernmost and northernmost provinces) are both very distant from Malé. A similar pattern may be observed in relation to the geography of tourist facilities. The spatial distribution (Figure 2) of this driving sector of the national economy is marked by the contrast between an undeniable concentration of facilities in the central atolls (Kaaf and Alif Alif), the marginalization of many outer atolls, and the significant number of facilities located in outlying atolls, such as Noon and Gaaf Alif, which enjoy better access to supplies of goods and services. Similar observations apply to other areas of human geography, such as waste and energy management systems (Ministry of Housing and Environment, 2010c, 2010d; Ministry of Environment and Energy, 2013b; Malatesta et al., 2015). The key policy implication-at the national level-of these geographical features is the need for flexible measures that may be applied to different scales and to an extremely heterogeneous set of demographic, ecological, and socio-economic contexts.

\footnotetext{
${ }^{1}$ In 2016, in the context of a broader survey carried out by the MaRHE Center, we conducted 25 in-depth interviews with 15 members of island or atoll councils, 10 tourist operators (resort managers), and five environmental activists, given that the main objective of our research is to integrate the reading of environmental policies with an understanding of the choices, knowledge, and practices adopted by actors at the local scale. Because this paper is based on a review of the literature and the content analysis of textual documents, we do not report the narratives that emerged from these interviews; nonetheless, the information provided by our informants helped us to choose list of laws, programs, and reports to include in our analysis.

2 There are often significant discrepancies between official records and the effective demographic structure. Therefore, we have integrated official census data with other sources such as Maps of the Maldives 2016 (Water Solutions, 2016) and Maldives Energy Outlook for Inhabited Islands (Ministry of Environment and Energy, 2013b).
} 
Figure 1: Map of the Maldives, Map No. 4479, 2012.

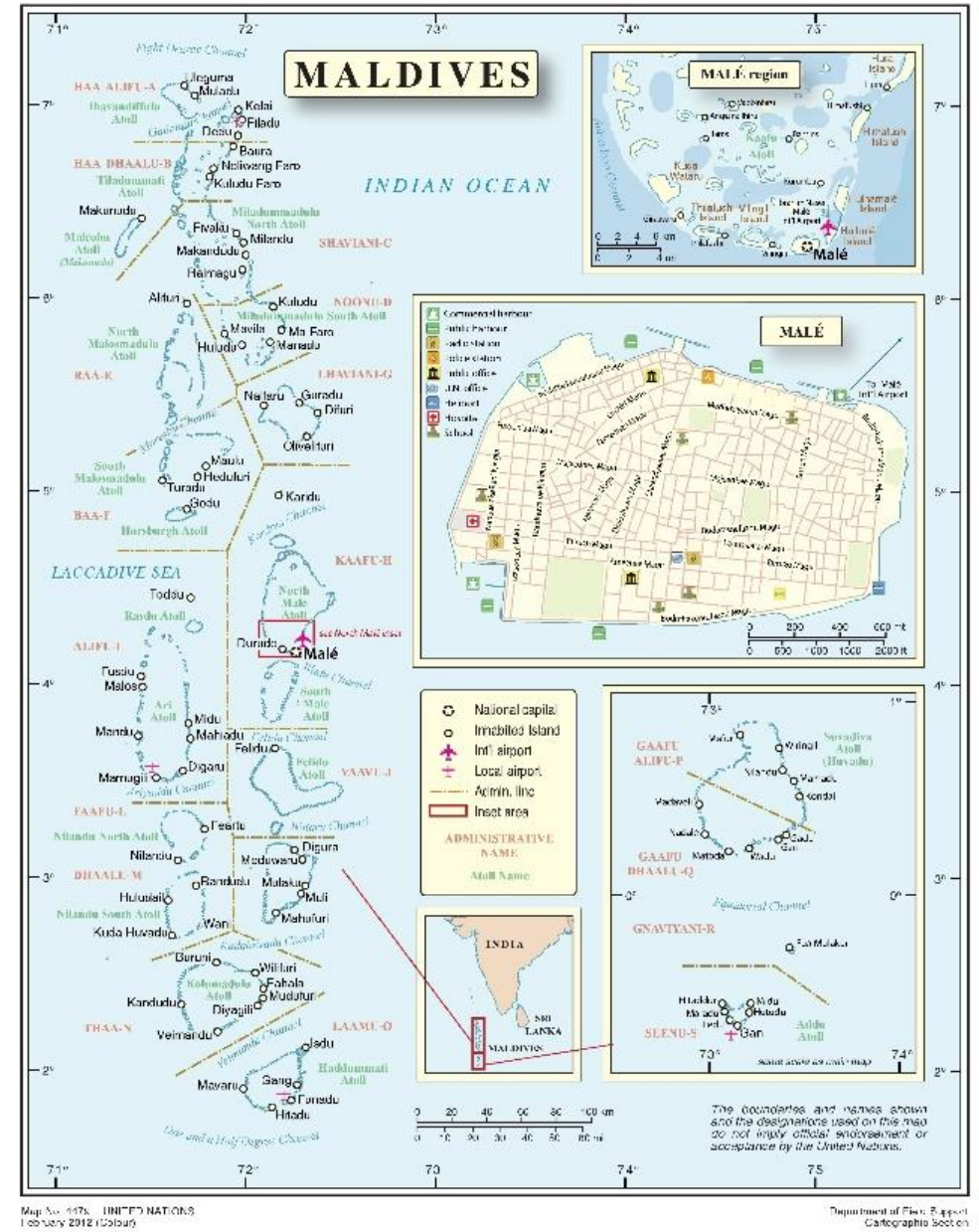

Source: United Nations, 2012, ttp://www.un.org/Depts/Cartographic/.

In light of the framework outlined above, we might argue that the human geography of the Maldives speaks to a key theme in island studies, namely "the theoretical, metaphorical, real and empirical power and potential of the archipelago" (Stratford et al., 2011, p. 113). More specifically, interrelations, connections, and disconnections among local systems, and between the capital and the other islands, are the main features shaping the spatial dynamics of the state.

Furthermore, the characteristics of the human geography of the Maldives suggest the need for geographers to combine their reading of local dynamics with an understanding of supra-local and global processes. Generally speaking, the trans-scalar perspective is essential to any discussion of the responses adopted by local communities to cope with environmental challenges (Kates \& Wilbanks, 2003), and, specifically in the study of island systems, "it is important to see local-level risks as outputs of increasingly global political and economic systems and of physical processes that are global in scale" (Pelling \& Uitto 2001, p. 52). 
Figure 2: Spatial distribution of tourist facilities.

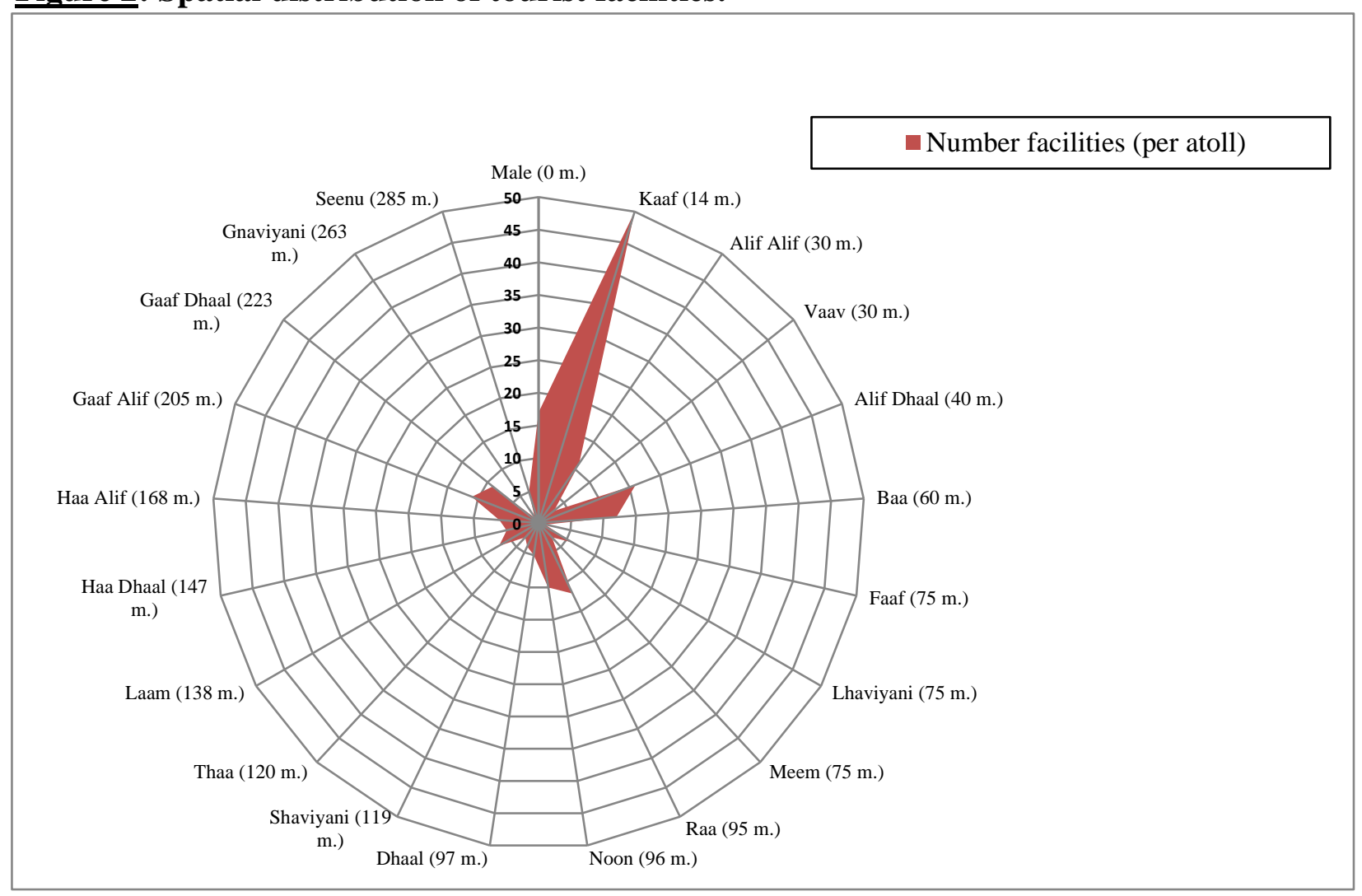

Source: Malatesta and Schmidt di Friedberg, data: Maps of the Maldives. The Complete Guide to the Atolls \& Islands of the Maldives.

\section{The regional scenario}

Two authoritative contributions on the history of the Indian Ocean (Pearson, 2003; Alpers, 2014) have identified contemporary environmental challenges as key to understanding the geographies and politics of the region. In relation to the recent debate on the regional environmental crisis, three key aspects emerge: namely the geopolitics of climate change (Rumley, 2010; Hommel \& Murphy, 2013), the need to define a roadmap for environmental action at the regional scale (Llewellyn et al., 2016), and the influence of international organizations (Vink, 2007) on regional planning and cooperation initiatives.

Rumley (2010, p. 147) emphasizes the centrality of this region for any "critical review of the ways in which the interrelationship between the politics and geopolitics of climate change and development have been portrayed." He bases this reading on an analysis of the involvement of geopolitical players in international meetings (especially the 2009 Conference of the Parities in Copenhagen), and the level of commitment of regional actors to international protocols. Far from claiming an arbitrary homogenous status for the Indian Ocean region, Rumley (2010, p. 150) defines this area as a complex conundrum since the overall causes of greenhouse gas emission vary both by level of economic activity as well as economic development." Although Rumley does not specifically mention the Maldives, it is clear that this archipelago occupies a key position within such a conundrum. Notably, the country's contribution to the level of gas emissions is limited compared to the region's leading economies, while its exposure to the consequences of climate change at regional and global scales is considerable. In the second part of this paper, we argue that this imbalance is one of the fundamental narratives within the so-called 'lexicon of risk'.

Llewellyn, English, and Barnwell (2016) more directly invoke the need to read the environmental policies of individual states in light of their regional context, concentrating their analysis on the human exploitation of marine resources such as fishing, marine mining, and tourism. 
In their paper, they emphasize that the use of these assets can generate a readable effect on different scales, from the local to the macro-regional. Again the Maldives play a prominent role, not only due to their central location within the space of the Indian Ocean, but also given the strategic function of sectors such as fishing and tourism within the national and regional economies. In the context of this paper, we suggest that it is crucial to assess the consequences of human activity in these sectors for social and environmental systems at the local and national scales.

The development of environmental policies, human marine activity, and the discourse on climate change (Donner \& Webber, 2014; Kothari, 2014) in the region have a series of implications for international relations. Although we do not here discuss the geopolitics of the Indian Ocean (instead focusing on how environmental priorities have contributed to constructing a certain image of the Maldives in the regional and international context), one geopolitical factor that is significant for our analysis is the role played by international agencies, among others UNDP, UNFCCC, the World Bank, and FAO, in promoting and implementing socio-environmental strategies and plans. As suggested by Rumley (2010), this is anything but a marginal consideration when seeking to understand how the politics and geopolitics of climate change and development may be interrelated. Notably, international consensus concerning the role of these agencies is one of the drivers of contemporary environmental policies across the region. For instance, UNDP is actively involved, as partner or promoter, in many actions promoting climate change adaptation and mitigation in the Maldives, such as the Tourism Adaptation to Climate Change (TAP), the Integrating Climate Change Risk to Resilient Island Planning project (ICCR), and the Enhance National Capacity for Disaster Risk Reduction and Management in Maldives project (DRRM).

Furthermore, we cannot overlook the fact that, due to its geographical location (Figure 3), the archipelago plays a geostrategic function within the regional chessboard, in particular, in the context of Sino-Indian rivalry, recently defined by Brewster (2015) as 'the' Indian Ocean dilemma.

\section{Islands and Future Earth: vulnerable places?}

It is necessary to balance perspectives that posit small islands as "characterized by narrow resource bases and dependency on links to the outside world, and by their limited ability to determinate the actual characters of those links" (Baldacchino \& Niles, 2011, p. 1) with those perspectives that emphasize small islands as sights of innovation, with the potential to serve as global trendsetters (e.g., Baldacchino, 2010). Such a balance can enrich critical reflection on the adoption of 'vulnerability' and 'isolation' as key categories defining the human geographies of islands and island states (Baldacchino, 2004; Trablesi, 2005; Depraetere, 2008a, 2008b; Moore, 2010; Kelman, 2010; Taglioni, 2011; Jędrusik, 2011).

Recently, the scientific debate on the vulnerability of island states has encouraged a re-reading of the paradigm "which describes island social realities and histories through the lens of vulnerability" (Moore, 2010, p. 119). The dominance of the vulnerability paradigm, namely the adoption of vulnerability as 'the' geographical feature defining island systems, generates two consequences: the production of general categories "in the international global climate change arena" (Moore, 2010, $\mathrm{p}$. 116), and the construction of a geographic imagery that frames small islands as un-resilient places and endorses interference and action on the part of external actors and agencies. According to Moore (2010, p. 121), this dominance is based on the vagueness of the term 'vulnerability', which "allows for a great deal of work to be done in its name." A direct political consequence of this mechanism is the institutionalization, via a massive body of assessments, reports, and rankings, of the vulnerability of small islands as an unquestionable assumption for environmental policies at international and regional levels. In the Maldives, this process bears particular weight, due to the international definition of the country as "the most vulnerable" in terms of sea-level rise (Ghina, 2003; Moore, 2010). The joint effects of the discourse on climate change and the institutionalization of small island vulnerability, according to Kelman (2014, p. 122), produces another key outcome: namely that "constructing a narrative featuring islands that are disappearing due to their physical characteristics 
[from the] climate change hazard obscures the wider vulnerabilities facing SIDS", in other words, the complex set of challenges and transformative forces small islands deal with.

This is not a merely speculative or epistemological topic. In practice, the vulnerability of the Maldives has become a prominent category within national and international discourse on climate change. This prevailing narrative has been reinforced by:

a massive plethora of official reports and documents published by international agencies [and national actors]. For instance, UNDP (2010a) adopted 'geographical', 'socio-economical' and 'environmental vulnerabilities' as interpretative frameworks to describe the 'development context' of the Maldives (Malatesta et al., 2015, p. 26).

Already in 2003, Ghina (2003, p. 139), reporting on the status of sustainability policies across the region, described the Maldives as "the typical small island developing state in the Central Indian Ocean", characterized by "ecological fragility and economic vulnerability" to climate change. Furthermore, UNDP (2010b, p. 2), currently a leading voice in the environmental discourse in the Maldives (see Footnote 3) has affirmed, with the aim of pointing up the inadequacy of national strategies for addressing environmental vulnerability, that "the most serious underlying driver of increasing vulnerability to climate change in the Maldives is the absence of a systematic adaptation planning." Two years after this statement by UNDP, the Maldives' Ministry of Environment and Energy listed, in the context of the official State of the Environment document, the "special vulnerability of the low lying small developing island states to the predicted climate change" (Ministry of Environment and Energy, 2012b, p. 14) among the priorities for domestic environmental policy. In 2008, the general framework of the National Adaptation Plan (NAPA), a key document for the definition of national environmental policies, had already been based on the identification of sectors vulnerable to change. The theme recurs in the most recent ministerial documents (Ministry of Environment and Energy, 2015a, 2015b), in particular in the statement by the Minister Thoriq Ibrahim that "the Maldivian Island are only in its kind in the world. The coral nation is also one of the islands considered the most vulnerable to climate change" (Ministry of Environment and Energy, 2015a, p. 5). Significantly, the National Adaptation Plan of Action, the State of the Environment 2011, and the Climate Change Policy Framework were published during three different presidencies, providing us with an indication of the 'resistant nature' of this narrative.

\section{The Maldives: climate change adaptation (CCA) as 'the' environmental priority}

The geographical and social features defining the Maldives as a country threated by climate change have been discussed from different perspectives: climate and geomorphology (Hay, 2006), social and socio-political implications (Ghina, 2003; Sovacool, 2012; Kothari, 2014; Arnall \& Kothari, 2015) and media discourse (Gay, 2014). As previously stated, we are interested in the evolution of environmental policies and the associated emergent dialectics. Despite UNDP's 2010 statement that "systematic adaptation planning" was lacking in the Maldives, during the period examined here (2003-2016) the Maldivian political leadership has engaged in intense legislative activity. Broadly speaking, our study period focuses on the last three presidencies: Maumoon Abdul Gayoom (last mandate: 2003-2008), Mohamed Nasheed (2008-2012), and Abdulla Yameen Abdul Gayoom (2013present).

The significance of the body of legislation produced and the institutionalization of competences and agencies responsible for environmental protection (most notably the Environmental Protection Agency) should not be underestimated. In the context of this paper, we focus on the most representative legislative measures:

- National Adaptation Plan of Action (2008)

- Strategic National Action Plan for Disaster Risk Reduction and Climate Change Adaptation 2010-2020 (2009) 
- Maldives Climate Change Policy Framework (2015).

In practice, this list allows us to discuss the elements of continuity and discontinuity that, over the last three presidencies, have characterized the discourse on vulnerability to climate change. This corpus should be read, however, in light of the Environment Protection and Preservation Act of Maldives, Law n. 4/93, published by the Ministry of Environment and Energy in 1993, which continues to provide the main reference framework for national policies. It remains particularly relevant to plans and acts regarding protected area management, environmental impact assessment, and waste management.

The National Adaptation Plan of Action (NAPA) represented a key step in the definition of the adaptation policies. One of its most interesting aspects was its aim to integrate different levels of intervention: policies, institutional activities, awareness campaigns, and the management of local systems. A careful reading of the NAPA also provides us with further insight into the strategies of recent years. In fact, in the case of the Maldives, the paradigm defined as CCA has been consistently combined with measures aimed at risk mitigation. Consequently, it would be more appropriate to use the acronym CCA(M), that is to say, Climate Change Adaptation (and Mitigation). Of course, this distinction calls to mind well-known historical transitions within international agendas, namely the shift from a paradigm of 'mitigation', to one of 'adaptation' and, most recently, to 'resilience'. In this case, we refer mainly to the use of these terms within the political agenda. As pointed out in the first part of the paper, the transition from a paradigm of mitigation to ones of adaptation and resilience has been extensively discussed in the literature (Adger et al., 2009; Pelling, 2011; Kelman, 2014). However, 'mitigation', 'adaptation', and 'resilience' are simultaneously present in Maldivian environmental policies and our reading of the body of legislation produced over recent decades suggests that it is more useful to assess how these paradigms work together, than to separate them on a chronological basis.

The Strategic National Action Plan for Disaster Risk Reduction and Climate Change Adaptation 2010-2020 (SNAP) may be said to mirror the climate change policies of the Mohamed Nasheed presidency. Furthermore, it is a clear example of the quest for synergies among different paradigms, given both the reference in the title to the integration perspective discussed in the literature (Schipper \& Pelling, 2006; Birkmann \& von Teichman, 2010) and the plan's stated overall objective: "essentially SNAP aims to build the resilience of the nation and the island communities to disasters and climate change impacts $[. .$.$] by incorporating risk reduction into the strategy for development"$ (Republic of the Maldives, 2009, p. 11). According to the reports from the preliminary roadmap, consisting of several workshops that took place in August 2009, the political goal was to demonstrate the government's commitment and to reinforce the status of climate change as the top priority on the national agenda. The SNAP document defined this agenda as comprising four strategic areas:

- Enabling environment towards good governance

- Empowered and capable communities

- Resilient communities with access to technology, knowledge, and other resources

- Risk-sensitive regional and local development.

The most interesting aspects of SNAP were the attempt to integrate these strategic areas with the overall framework provided by NAPA and, above all, the emphasis on promoting resilience strategies at the local scale. Importantly, two years after the publication of SNAP, the Ministry of Housing and Environment published the Survey of Climate Change Adaptation Measures in the Maldives, which provides key information about infrastructural adjustments at the local island level.

Six years later, the Ministry of Environment and Energy (2015a, p. 10), through the Climate Change Policy Framework, reinforced this approach, stating that "climate change is a cross-cutting development issue as it affects every aspect of the Maldivian way and livelihoods."

There is no doubt, however, that over the relatively long time period examined here (which has been marked by a series of changes in the political arena), many key political areas have been affected by instability. In relation to tourism policies in particular, changes in power relationships among different stakeholders have shaped a complex panorama (Bowen et al., 2016). The same 
applies to the use of marine resources and infrastructure policies. During the current presidency of Abdulla Yameen Abdul Gayoom, environmental priorities have shifted with respect to the guidelines laid down by the previous government. The present political agenda is characterized by investment in major infrastructural projects and the urban development of Hulhumalé island. Hulhumale is an artificial island close to the capital, and has been defined as the "most ambitious land reclamation and urban development project undertaken by the Government of Maldives" (https://hdc.com.mv/hulhumale). Hulhumalé is planned to be a combination of residential, commercial, and industrial areas, and the most highly populated island of the entire archipelago.

Nonetheless, it should be noted that within the regulatory framework, the narrative that we have termed the 'lexicon of risk' has been systematically reinforced and constantly legitimized. This narrative has been based on the constant reiteration of $\mathrm{CCA}(\mathrm{M})$ as a national priority and it has contributed to making 'vulnerability' a key driver in the construction of the geographical imaginary of the country.

\section{Becoming a 'symbol'}

In his introductory remarks to the 2015 Climate Change Policy Framework, Minister Thoriq Ibrahim claimed national commitment to $\mathrm{CCA}(\mathrm{M})$, while emphasizing the continuity in governmental policies over the past decades: "We have invested extensively on climate change adaptation and mitigation" (Ministry of Environment and Energy, 2015a, p.5).

In the current paper, we do not set out to discuss this political continuity, confining ourselves to noting that, on the contrary, there has been marked discontinuity in some areas of environmental policy-especially between the presidencies of Mohamed Nasheed (2008-2012) and Abdulla Yameen Abdul Gayoom (2013-present) - which would merit careful analysis in its own right. Rather we wish to note that the key elements of the normative body discussed here have been endorsed, and even legitimized, by a series of presidential statements and official declarations. Such statements contribute to reinforcing particular national narratives, especially the image of a vulnerable country facing dramatic environmental threats on the global chessboard. The discourse on vulnerability, as noted in the first section of this paper, has been based on emphasizing the distance between responsibility for emissions and the effects of climate change. The Maldives has been repeatedly characterized as a country that generates a low level of emissions yet has to cope with a severe degree of exposure to the consequences of climate change: "While Maldives has not significantly contributed to the causes of climate change, the slow pace of international negotiations to limit global warming is therefore a cause for deep concern for the country" (Ministry of Environment and Energy, 2015a, p. 10). These same arguments were put forward in relation to the situation of Small Island Developing States in general, during the intervention of President Mohamed Nasheed at the 2009 Conference of the Parties.

The link between highlighting the country's vulnerability and assigning political priority to CCA(M) is the common legacy of all three presidencies included in our analysis. In 2006, President Maumoon Abdul Gayoom stated that "To the three hundred thousand inhabitants of the Maldives none of these threats compare, in magnitude and likelihood, to global climate change and consequent sea level rise" (Ministry of Environment, Energy and Water, 2007, p. 3). In 2010, President Mohamed Nasheed, in stressing the economic and ethical consequences of hydrochlorofluorocarbon emissions (HCFC), claimed that "Imported diesel is not just dirty, it is also extremely expensive" (Nasheed 2010, p. 5). Recently, President Abdulla Yameen Abdul Gayoom declared:

Climate change is the most pressing contemporary challenge faced by small island developing states such as the Maldives, to their sustainable development agendas [...] the low-lying nature of our islands, coupled with their geographic dispersion, fragile environment, remoteness, vulnerability to natural disaster, and narrow economic base, further exacerbate our vulnerability to climate change (Ministry of Environment and Energy, 2015b, p. 1). 
This narrative may have also acted as an agent of national cohesion, going right back to the opening speech of President Maumoon Abdul Gayoom at the United Nations General Assembly on Environment and Development in 1987. During his address to the UN delegates, he defined the consequences of global environmental change as the "death of a nation." In 1989, President Maumoon Abdul Gayoom reinforced this narrative at the Small States Conference on Sea Level Rise in Malé by stating:

There must be a way out. Neither the Maldives nor any small island nation wants to drown. That's for sure. Neither do we want our lands eroded nor our economies destroyed. Nor do we want to become environmental refugees either. We want to stand up and fight.

Thus, environmental policy statements emphasize the fact that the nation and the Maldivian people, as a community, are both under threat. As expressed by President Abdulla Yameen Abdul Gayoom: "As the Republic of Maldives is one of the Small Island Developing States that is most vulnerable to climate change, addressing the related issue is crucial and essential to its very existence as a nation" (Ministry of Environment and Energy, 2015a, p. 4). This pattern is clearly reflected in the 'vision' informing the recent Climate Change Policy Framework: "to recognize the status of Maldives as a nation suffering from the adverse impact of climate change" (Ministry of Environment and Energy, 2015a, p. 20).

Furthermore, this narrative has shaped the country's image within the international community. As pointed out by Rumley (2010) and Gay (2014), the discourse on climate change can play a key role in the geopolitics of the region. The 'lexicon of risk' presents the Maldives as a vulnerable country, with a low level of responsibility for causing climate change, but, at the same time, as a strongly committed actor within the international scenario. Both in general terms: "The Maldives is determined to be part of a global solution by committing to achieve a low-emission development future" (Ministry of Environment and Energy, 2015a, p. 10), and in terms of concrete environmental strategies with global repercussions: "In having a radical economy-wide carbon neutral plan [...] the Maldives has become an exemplary country and forerunner in the advocacy for climate change action in the world" (Republic of the Maldives 2009, p. 13).

We might argue that the narrative reinforcing the idea of a 'community under threat' together with the image, presented on the international stage, of a country locally facing the consequences of a global process (climate change) have been acting as drivers in the construction of contemporary Maldivian 'nation-ness'. From a socio-constructivist perspective (Anderson, 1983; Hobsbawm, 1990; Minca \& Bialasiewicz, 2004), nations are essentially socio-political constructs-defined as 'imagined communities'-built up by shared narratives and geographical imaginaries produced by the political and cultural elites. In the case of the contemporary Maldives, the vulnerability paradigm and 'the lexicon of risk' aim to reinforce the 'nation-ness' of the communities living across the archipelago. In this paper, we point out that Maldivian environmental policies (in the form of a body of laws, reports, plans, and regulations) consolidate these two narratives, and we discuss the inextricable link between the country's contemporary political geography and the language and paradigm guiding the formulation of these policies.

\section{Social response to change: local perspectives}

The social implications of the discourse on climate change have been discussed by Sovacool (2012), who investigated the perceptions of policy makers and local institutions, thereby contributing to our knowledge of the adjustments adopted by island systems in the face of environmental change. More recently, Arnall and Kothari (2015) focused on the relationship between environmental challenges and migration processes, proposing a critical reading of the perceptions of stakeholders. 
In the introduction to the present paper, we ourselves stressed the need for an archipelagic country to promote synergies between action to address challenges at the supra-national scale and the adjustments and strategies promoted by small islands. This in turn prompted us to examine the complex relationship between national policies and the environmental priorities of island communities, and to take a specific look at the adjustments and strategies implemented al the local scale.

Sovacool (2012) examines the dialectic among local actions, national policies, and supranational programs, providing an overview of the Integrating Climate Change Risks into Planning Resilient Island in the Maldives program (ICCR): a project internationally funded by UNDP and the Least Developed Countries Fund and nationally implemented by the Ministry of Housing and Environment of the Maldives (UNDP, 2010b). He lists the sectors that are potentially vulnerable to the impact of climate change: human settlements, critical infrastructures (above all, harbours and piers), tourism, fisheries, water management, and coral reefs. In keeping with the government view and international reports, the ICCR declares these areas to be the country's environmental priorities. Examining these priorities alongside the measures commonly adopted on the small islands (seawalls, beach replenishment, or groynes), sheds light on the complex scenario faced by small island communities and the impact of environmental changes at the local scales. De facto, the measures adopted on the inhabited islands concern the priority areas. Furthermore, Sovacool (2012, pp. 746748) argues that the dialectic between national plans and local actions should not be analyzed in terms of differences in priorities, but in relation to three main challenges "at the infrastructural level [...] the lack of resources available [...] at the institutional level [...] the lack of coordination [and] at the community level [...] the preference of hard adaptation measures and short-term thinking." These challenges thus call for the integration of the $\mathrm{CCA}(\mathrm{M})$ framework and the geographical and social features of inhabited islands.

In keeping with national $\mathrm{CCA}(\mathrm{M})$ strategies, in 2011, the Ministry of Housing and Environment published the final report of the Survey of Climate Adaptation Measures in Maldives, presenting both the benefits and the challenges associated with the ICCR. The survey-conducted on 40 inhabited and resort islands-was designed to assess the existing infrastructural and regulatory measures adopted by local islands to deal with the effects of sea-level rise. "The purpose of the survey is to provide baseline information on adaptation activities in Maldives, and to identify adaptation options currently being used that may be suitable for replication" (Ministry of Housing and Environment, 2011, V). The spectrum of the infrastructural adjustments adopted may be grouped into two categories: hard-engineering measures and soft-engineering measures. Hard measures:

guarantee no further retreat of existing beach line and wave overtopping. They include seawalls, bulkheads and revetments. [furthermore] Shoreline stabilization measures are designed to modify the coastal processes to achieve shore stabilization. The most common materials used for construction are dead coral, sand-cement bags, concrete piles, armour rock and sheet piles (Ministry of Housing and Environment, 2011, p. 6).

\section{Meanwhile:}

the most common quick-fix soft engineering adaptation measures are beach replenishment, temporary seawalls or groynes, ad hoc seawalls and revetments, and submerged geo-textile tubes. Long-term adaptation measures include land use controls or setbacks, coastal vegetation retention, coastal ridge maintenance, coastal structural design changes, natural drainage and artificial reefs (Ministry of Housing and Environment, 2011, p. 56).

The study is a good example of frequent attempts on the part of government to incorporate acknowledgement of local strategies into the design of national policies. This undoubtedly represents 
one of the most promising approaches to developing environmental policy in island states, especially in light of the geographical features described in the opening paragraphs of this paper. Although the survey only investigated infrastructural measures, it yielded two key findings: the crucial role of soft adjustment, that is to say, of low-impact adaptation measures (such as temporary and removable groynes or ad hoc seawalls), and the need for nationwide awareness campaigns designed to improve local skills and knowledge. Moreover, as a result of the surveys conducted by Sovacool, the Ministry of Housing and Environment researchers were advised to integrate description of actions (infrastructural and other measures deployed by inhabited islands to cope with rising sea levels) with analysis of the inhabited islands' environmental challenges.

Official documents and scientific papers report both energy supply of peripheries and sustainable waste management as critical environmental challenges for local islands, and key issues for CCA(M) strategies (van Alphen et al., 2007; Environment Research Centre, 2008a, 2008b; JICA, 2009; Ministry of Housing and Environment, 2010c, 2010d; Ministry of Environment and Energy, 2012a, 2013a, 2013b; Pearson, 2013; Colombo et al., 2014; Kelman, 2014). We now focus on these environmental challenges in keeping with our aim to examine the complex set of strategies developed by human communities, here defined as 'social response'. In the Maldives, we may define the social response to change as the set of adjustments (political, cultural, technological, and social) that local communities adopt to cope with the exogenous changes impacting the geographies of islands. These strategies may be studied by focusing on different levels: Sovacool, by investigating the perceptions of local administrators, explores the institutional level; the Ministerial report, by assessing the effectiveness of soft adjustments on a sample of inhabited islands, describes the infrastructural level; our previous study on collective waste management points to the role of local knowledge and practices in shaping these adjustments (Malatesta et al., 2015).

The geographer Robert Kates (1971) proposed a groundbreaking analysis of socioenvironmental interrelationships in cases of chronic and pervasive environmental hazards, thereby bringing to light the entire set of adjustments adopted by local communities to deal with environmental changes: infrastructures, practices, knowledge, rules, behaviors, values, and representations. Although we should acknowledge the link between this perspective and a specific historical context (and theoretical framework), and, consequently, avoid the risk of espousing 'universalistic models', Kates's approach continues to provide a valuable framework for reading the strategies deployed by small island communities to cope with environmental change and challenges. This is essentially because, as suggested by Kates, the 'human use system'-that is to say, the complex set of knowledge and behaviors underpinning local adjustments-is more important than policies and infrastructural measures for enabling our understanding of the social response to environmental changes. Energy production and waste management are prime examples of how this framework may be helpful for overcoming the dialectics discussed in the first part of the paper. Indeed, we might argue that the Climate Change Risk into Resilient Island Planning Project in the Maldives indirectly reflects such an approach.

Table 1: Kerosene and diesel consumption on small islands (average).

\begin{tabular}{|c|c|c|c|}
\hline Island Pop. & \begin{tabular}{|l} 
Island \\
Number \\
\end{tabular} & Per Day / Litre & Per Year / Litre \\
\hline Pop. $\leq 500$ & 34 & 220 & 81,250 \\
\hline Pop. $500 \leq 1000$ & 57 & 410 & 150,000 \\
\hline TOT & 91 & & \\
\hline
\end{tabular}

Source: Malatesta \& Schmidt di Friedberg, data: Ministry of Environment and Energy, $2013 b$. 
Geographically speaking, Malé is the core area of a country composed of hundreds of small islands on which over $98 \%$ of the energy supply is produced via the combustion of imported diesel and kerosene. According to the official data (Ministry of Environment and Energy, 2013b), Malé accounts for over $57 \%$ of the total production and consumption of energy. Table 1 highlights selected focal points of this consumption landscape. Villages of under 1,000 inhabitants, approximately 50\% of the inhabited islands, depend almost entirely on on-site powerhouses (191 across the whole archipelago) and, above all, on the supply of tanks of kerosene and diesel. These powerhouses, on islands with under 500 inhabitants, burn 220 litres of fuel per day to cater for local energy requirements. This amount rises to 410 litres per day on islands with 500 to 1000 inhabitants. These averages are considerably lower than those reported by resort-islands. Even with the same number of people on the island (under 500 inhabitants, including both resort staff and visitors), during the full occupancy period, a resort can burn more than 3,500 litres of kerosene or diesel per day. Clearly this represents a crucial environmental challenge for peripheral and small systems. On a large number of small islands, electrical wiring was introduced no more than fifteen years ago, and in the Maldives as a whole, only in recent decades. These data confirm the need for a reading of the spatial features defining Maldivian geography and suggest that national energy policy should take into account the choices, regulations, and adjustments put in place by local communities to deal with contemporary challenges.

Waste management, another key environmental issue at the local scale, may be read in light of the changes that the country has been undergoing. Notably, the introduction of plastic, food packaging, and materials such as asbestos, has greatly impacted on waste management practices and strategies. The convoluted waste management scenario in the Maldives is characterized by the coexistence of radically different models, and by a dialectics, which often plays out in a complex manner, between top-down infrastructural measures and local knowledge and practices. The dumping of waste and other materials at sea and the open-air burning of solid waste comprise the prevailing systems on a large number of the smaller islands. At the same time, attempts to provide waste treatment and reuse or recycling facilities face serious obstacles in relation to obtaining financial support and managing spatial features: notably, access to or exclusion from transport networks. In sum, we are looking at "a dialectic between regional (or national) top down approaches and local knowledge and practices [and] how human geography of local communities [are] strongly connected to the strategies and adjustments they have developed to deal with environmental, social and political challenges" (Malatesta et al., 2015, p. 31).

In light of this complex set of socio-environmental interrelations, we argue, in line with Sovacool, that priorities do not differ greatly across scales: rather, there is a need to act on the availability of resources, take local knowledge and adjustments as the starting point for analysis and action, address the current lack of coordination among scales, and promote long-term and synergic plans.

Including this approach in the development of national environmental policies requires a trans-scalar perspective, the promotion of soft adjustments, the empowerment of alternatives to infrastructural measures, and the overcoming of vulnerability as the key category defining island geography. Ultimately, identifying the body of practices, knowledge, and strategies adopted at the local scale means understanding the complex responses of local communities to environmental challenges. Thus, local choices and knowledge are the ideal basis on which to plan strategies that will be effective in acting on local geographies. The guiding principle is that of starting from the multiple adjustments through which small island communities cope with change, instead of merely considering them as vulnerable to change.

\section{Geographies-Paradigms-Futures?}

Both Sovacool and the Ministry of Housing and Environment conclude their report by recommending that resilience should be fostered on the smaller islands by drawing on indigenous knowledge of local island geographies. This advice confirms Kelman's observation that small island communities have 
a long history of addressing social and environmental challenges. In a previous paper (Malatesta et al., 2015), we stressed the role of such 'indigenous knowledge' and practices in the development of environmental policies that integrate local action with top-down infrastructural measures. In the current paper, we claim that the influence of climate change discourse on Maldivian environmental policies is a major obstacle to the implementation of this recommendation. Several authors (Barnett \& Campbell, 2010; Donner \& Webber, 2014; Gay, 2014; Kothari, 2014) point out the influence of climate change discourse on both the environmental laws of small island states and international programs. This effect may be explained by the force of the vulnerability paradigm shaping the geographical imaginary of small islands. The Maldives represent an enlightening example of this influence, in that "the significant threat to the Maldives from climate change is real, but many other development challenges also need to be overcome" (Kelman, 2014, p. 122). Our research addresses the emerging dialectic between the vulnerability paradigm and local environmental challenges, which is a pivotal issue not only for the Maldives, but for the environmental policies of island states more generally. Campbell $(2009$, p. 94) reminds us that "vulnerability was not a particularly marked characteristic of island societies and communities and, accordingly, islands are not inherently vulnerable places."

The discourse of vulnerability is a construct that features in both national policies and international strategies. For this reason, we have based our analysis on a re-reading of the lexicon used and the priorities identified in national environmental laws. In addition to the dominant influence of the CCA framework on environmental laws and plans, in the case of the Maldives, this re-reading shows the joint effects of two factors: the dominance of the national and supra-national scales; and the notion of 'vulnerability' as a key element in the ongoing construction of the country's geographical imaginary. As geographers, we are interested in these two elements because they highlight the reciprocal relations between environmental discourse and the geography of island countries.

In the Maldives the dialectic between center and periphery and the geographical features discussed in the first part of this paper play a key role in defining such reciprocity. As stated above, the geography of the Maldives is structured around a spatial antithesis between concentration and dispersion. We might argue that a significant part of the political action of the state is aimed at overcoming the limitations associated with this antithesis. Our content analysis of selected key environmental policies pointed to the emergence of two political strategies: presenting climate change as a threat to the nation and seeking to establish the national scale as the main geographical framework. As shown by other authors (Farbotko, 2010; Yamamoto \& Esteban, 2010; Donner \& Webber, 2014), climate change discourse is closely linked to the political geography of island states. In the case of the Maldives, this link may be identified in the attempt (by state) to overcome the limitations associated with the spatial antithesis between concentration and dispersion. Hence, we have primarily focused our research program on the local level and on the adjustments and strategies implemented by inhabited islands at the local scale, on the basis that neither national policies nor international interventions address the complexity of the environmental challenges facing smallisland systems beyond the threats of climate change. We have discussed the dialectics among scales underlying environmental policies, viewing them as a transversal element in our re-reading of the environmental discourse on small island states. Fostering small-island resilience by incorporating indigenous knowledge and input about local islands' geographies means working on the complex body of social constructions, sense of place, spatial features, representations, practices, and knowledge defining socio-environmental relationships of small islands.

In conclusion, vis-à-vis the broader debate in island studies, we identify a number of topics deserving deeper discussion in future works on the environmental policies of the Maldives. Our reading of the Maldivian environmental policies points to the existence of powerful spatial dialectics and antitheses. At the supra-regional scale: the clash between national priorities and the global discourse on climate change. At the national scale: the considerable differences between the centre and the peripheries. At the supra-local scale: the emergence of spatial inequalities among local systems. Furthermore, in light of the debate on spatial interrelations among islands and within 
archipelagos, as geographers, we should investigate the possible interactions and synergies among all of these levels of analysis.

As shown in the second part of the paper, combining CCA(M) strategies with a 'social response to change' perspective is an approach that has already been implemented, de facto, in recent Maldivian policy documents: for example, in the Strategic National Action Plan for Disaster Risk Reduction and Climate Change Adaptation 2010-2020. Island studies should promote this approach as 'the' guiding principle: a paradigm with the power to transcend the limitations of the so-called 'lexicon of risk'. This paper addresses the importance of the CCA(M) framework within the national policies. In future studies, we aim to deepen the discussion on the social consequences of this process. Finally, in keeping with recent Indian Ocean studies, we need to map the complex 'cartography' of the actors involved in the geopolitics of the region (NGOs, international agencies, global stakeholders). Critically, this network strongly influences both future development policies and the resilience strategies of local communities.

\section{References}

Adger, W.N., Barnett, J., Brown, K., Marshall, N., \& O’Brien, K. (2013). Cultural dimensions of climate change impacts and adaptation. Nature, Climate Change, 3, 112-117. https://doi.org/10.1038/nclimate1666

Adger, W.N., Benjaminsen, T.A., Brown, K., \& Svarstad, H. (2001). Advancing a political ecology of global environmental discourses. Development and Change, 32, 681-715. https://doi.org/10.1111/1467-7660.00222

Adger, W.N., Dessai, S., Goulden, M., Hulme, M., Lorenzoni, I., Nelson, D.R., Naess, L.O., Wolf, J., \& Wreford, A. (2009). Are there social limits to adaptation to climate change. Climatic Change, 93, 335-354. https://doi.org/10.1007/s10584-008-9520-z

Alpers, E.A. (2014). The Indian Ocean in World History. New York: Oxford University Press.

Anderson, B. (1983). Imagined Communities: Reflections on the origin and Spread of Nationalism. London: Verso.

Arnall, A. \& Kothari, U. (2015). Challenging Climate Change and Migration Discourse: Different Understandings of Timescale and Temporality in the Maldives. Global Environmental Change, 31, 199-206. https://doi.org/10.1016/j.gloenvcha.2015.01.011

Baldacchino, G. (2010). Island enclaves: Offshoring strategies, creative governance, and subnational island jurisdictions. Montreal \& Kingston: McGill-Queen's Press.

Baldacchino, G. (2008). Studying Islands: On Whose Terms? Some Epistemological and Methodological Challenges to the Pursuit of Island Studies. Island Studies Journal, 3(1), 3756.

Baldacchino, G. (2004). The Coming of Age of Island Studies. Tijdschrift voor Economische en Sociale Geographie, 95(3), 272-283. https://doi.org/10.1111/j.1467-9663.2004.00307.x

Baldacchino, G., \& Niles, D. (Eds.). (2011). Island Futures: conservation and development across the Asia-Pacific Region. Tokyo: Springer. https://doi.org/10.1007/978-4-431-53989-6

Barnett, J., \& Campbell, J. (2010). Climate Change and Small Island States: Power, Knowledge, and the South Pacific. London: Earthscan.

Birkmann, J., \& von Teichman, K. (2010). Integrating disaster risk reduction and climate change adaptation: key challenges-scale, knowledge, and norms. Sustainable Science, 5, 171-184. https://doi.org/10.1007/s11625-010-0108-y

Bowen, D., Zubair, S. \& Altinay, L. (2016). Politics and Tourism Destination Development: The Evolution of Power. Journal of Travel Research. https://doi.org/10.1177/0047287516666719

Brewster, D. (2015). An Indian Ocean dilemma: Sino-Indian rivalry and China's strategic vulnerability in the Indian Ocean. Journal of the Indian Ocean Region, 11(1), 48-59. https://doi.org/10.1080/19480881.2014.994822 
Bryant, R.L. (1992), Political Ecology. An Emerging Research Agenda in the Third-World Studies. Political Geography, 11(1), 12-36. https://doi.org/10.1016/0962-6298(92)90017-n

Bryant, R.L-, \& Bailey, S. (1997). Third World Political Ecology. London: Routledge.

Campbell, J. (2009), Islandness. Vulnerability and resilience in Oceania. Shima: International Journal of Research into Island Cultures, 3(1), 85-97.

Colombo, A., Bettinetti, R., Strona, G., Cambria, F., Fanelli, R., Zubair, Z., \& Galli, P. (2014). Maldives: An archipelago that burns. A first survey of PCDD/Fs and DL-PCBs from human activities. Science of the Total Environment, 499-507. https://doi.org/10.1016/j.scitotenv.2014.08.013

Depraetere, C. (2008a). The Challenge of Nissology: A Global Outlook on the World Archipelago. Part I: Scene Setting the World Archipelago. Island Studies Journal, 3(1), 3-16.

Depraetere, C. (2008b). The Challenge of Nissology: A Global Outlook on the World Archipelago. Part II: The Global and Scientific Vocation of Nissology. Island Studies Journal, 3(1),17-36.

Deutsch, K.W. (1977). Some problems and prospects of ecopolitical research. In K.W. Deutsch (Ed.) Ecosocial Systems and Ecopolitics, A Reader on Human and Social Implications of Environmental Management in Developing Countries. (pp. 359-368). Paris: UNESCO.

Donner, S.D., \& Webber, S. (2014). Obstacle to climate change adaptation decisions: a case study of sea-level rise and coastal protection measures in Kiribati. Sustainability Science, 9, 331-345. https://doi.org/10.1007/s11625-014-0242-Z

Environment Research Centre (2008a). National Solid Waste Management Policy for the Republic of Maldives. Ministry of Environment, Energy and Water: Malé.

Environment Research Centre (2008b). Environmental and Social Assessment Framework, Maldives Environmental Management Project. Ministry of Environment, Energy and Water: Malé.

Farbotko, C. (2010). Wishful sinking: Disappearing islands, climate refugees and cosmopolitan experimentation. Asia Pacific Viewpoint, 51(1), 47-60. https://doi.org/10.1111/j.14678373.2010.001413.x

Gay, J.C. (2014). Le Réchauffement Climatique: l'instrumentalisation des Iles. L'Espace Geographique, 1, 81-89. https://doi.org/10.3917/eg.431.0081

Gayoom, M.A. (1989). Speech to the Small States Conference on Sea Level Rise, Malé.

Ghina, F. (2003). Sustainable development in small island developing states. The case of the Maldives, Environment. Development and Sustainability, 5, 139-165. https://doi.org/10.1023/A:1025300804112

Hay, J.E. (2006). Climate Risk Profile for the Maldives. Retrieved from http://www.environment.gov.mv

Hay, P. (2006). A Phenomenology of Islands. Island Studies Journal, 1(1), $19-42$.

Hobsbawm, E. (1990). Nations and Nationalism since 1780. Cambridge: Cambridge University Press.

Hommel, D. \& Murphy, A.A (2013). Rethinking geopolitics in an era of climate change. Geojournal, 78(3), 507-524. https://doi.org/10.1007/s10708-012-9448-8

Housing Development Corporation (2014). HulhuMalé Project. Retrieved from https://hdc.com.mv/hulhumale/

International Maritime Bureau (2009). Great Power Competition in the Indian Ocean. Retrieved from http://gentleseas.blogspot.it/

JICA (2009). Feasibility study for the application of photovoltaic power on Malé and Hulhumalé islands in the Republic of the Maldives. Japan International Cooperation Agency.

Jędrusik, M. (2011). Island Studies. Island Geography. But What is an Island?. Miscellanea Geographica - Regional Studies on Development, 15, 201-212.

Kates, R.W. (1971). Natural hazard in ecological perspective: Hypotheses and Models. Economic Geography, 47(3), 438-451. https://doi.org/10.2307/142820

Kates, R.W., \& Wilbanks, T.J. (2003). Making the Global Local, Environment, 45(3), 12-23. https://doi.org/10.1080/00139150309604534 
Kelman, I. (2010). Hearing local voices from Small Island Developing States for climate change, Local Environment. The International Journal of Justice and Sustainability, 15(7), 605-619.

Kelman, I. (2014). No change from climate change: vulnerability and small island developing states. The Geographical Journal, 180(2), 120-129. https://doi.org/10.1111/geoj.12019

Kothari, U. (2014). Political discourses of climate change and migration: resettlement policies in the Maldives. The Geographical Journal, 180(2), 130-140. https://doi.org/10.1111/geoj.12032

Llewellyn, L.E., English, S., \& Barnwell, S. (2016). A roadmap to a sustainable Indian Ocean blue economy, Journal of the Indian Ocean Region, 12(1), 52-66. https://doi.org/10.1080/19480881.2016.1138713

Malatesta, S., Schmidt di Friedberg, M., Pecorelli, V., Cajiao, M.A., \& Di Pietro A. (2015). The right place. Solid waste management in the Republic of Maldives: between infrastructural measures and local practices. Miscellanea Geographica. Regional Studies on Development, 19(2), pp. 25-32. https://doi.org/10.1515/mgrsd-2015-0003

Malatesta, S., Schmidt di Friedberg, M., Squarcina, E., Cajiao, M.A., \& Di Pietro A. (2014). Stato centrale e centri periferici: la geografia politica delle Maldive tra omologazione e segregazione, Scripta Nova, XVIII, 493.

Minca, C., \& Bialasiewicz, L. (2004). Spazio e Politica. Riflessioni di geografia critica. Padova: CEDAM.

Ministry of Environment and Energy (2015a). Maldives. Climate Change Policy Framework. Retrieved from http://www.environment.gov.mv

Ministry of Environment and Energy (2015b). The Maldives. A Climate Change Kaleidoscope. Retrieved from http://www.environment.gov.mv

Ministry of Environment and Energy (2013a). Agreements signed to establish a $40 \mathrm{~kW}$ solar photovoltaic system and a $5 \mathrm{~kW}$ ice making machine in Kaafu atoll Dhiffushi Island. Retrieved from http://www.environment.gov.mv

Ministry of Environment and Energy (2013b). Maldives Energy Outlook for Inhabited Islands. Retrieved from http://www.environment.gov.mv

Ministry of Environment and Energy (2012a). Maldives SREP investment plan 2013-2017. Malé: Ministry of Environment and Energy.

Ministry of Environment and Energy (2012b). State of the Environment. Retrieved from http://www.environment.gov.mv

Ministry of Environment and Energy (1993). Environment Protection and Preservation Act of Maldives, Law n. 4/93. Retrieved from http://www.environment.gov.mv

Ministry of Environment, Energy and Water (2007). National Adaptation Plan of Action. Malé: Ministry of Environment, Energy and Water.

Ministry of Housing and Environment (2011). Survey of Climate Change Adaptation Measures in the Maldives. Malé: Ministry of Housing and Environment.

Ministry of Housing and Environment (2010b). Developing a User Pays Framework for Island Waste Management Service. Malé: Ministry of Housing and Environment.

Ministry of Housing and Environment (2010c). Maldives National Energy Policy and Strategy. Malé: Ministry of Housing and Environment.

Ministry of Housing and Environment (2010d). Solid Waste Management Regulation 2010. Malé: Ministry of Housing and Environment.

Moore, A. (2010). Climate Changing Small Islands. Considering Social Science and the Production of Island Vulnerability and Opportunity. Environment and Society: Advances in Research, 1, 116-131. https://doi.org/10.3167/ares.2010.010106

Nasheed, M. (2010). Maldives Takes the Lead on HCFC Phase-Out. Retrieved from http://www.environment.gov.mv

National Bureau of Statistics (2014). Population and Housing Census 2014, Preliminary Results. Malé: Ministry of Finance \& Treasury. 
O'Riordan, T. \& Jordan, A. (1999). Institutions, climate change and cultural theory: towards a common analytical framework. Global Environmental Change, 9, 81-93. https://doi.org/10.1016/S0959-3780(98)00030-2

Pearson, M. (2003). The Indian Ocean. London, New York: Routledge. https://doi.org/10.4324/9780203414132

Pelling, M. (2011). Adaptation to Climate Change, From Resilience to Transformation. London, New York: Routledge.

Pelling, M. (1999). The political ecology of flood hazard in urban Guyana. Geoforum, 30, 240-261. https://doi.org/10.1016/S0016-7185(99)00015-9

Pelling, M. \& Uitto, J.J. (2001). Small island developing states: natural disaster vulnerability and global change. Environment Hazards, 3, 49-62. https://doi.org/10.3763/ehaz.2001.0306

Republic of the Maldives (2009). Strategic National Action Plan for Disaster Risk Reduction and Climate Change Adaptation 2010-2020. Malé: Republic of the Maldives.

Reynaud, A. (1984). Disuguaglianze regionali e giustizia socio-spaziale. Milano: Unicopli.

Rumley, D. (2010). Ideology, carbon emissions and climate change discourses in the Indian Ocean Region. Journal of the Indian Ocean Region, 6(2), 147-154. https://doi.org/10.1080/19480881.2010.537112

Schipper, L. \& Pelling, M (2006). Disaster risk, climate change and international development: scope for, and challenges to, integration. Disasters, 30(1), 19-38. https://doi.org/10.1111/j.14679523.2006.00304.X

Sovacool, B.K., (2012). Perceptions of climate change risks and resilient island planning in the Maldives. Mitigation and Adaptation Strategies for Global Change, 17, 731-752. https://doi.org/10.1007/s11027-011-9341-7

Stratford, E., Baldacchino, G., McMahon, E., Farbotko, C. \& Harwood, A. (2011). Envisioning the Archipelago. Island Studies Journal, 6(2), 113-130.

Taglioni, F. (2011). Insularity, Political Status and Small Insular Spaces: a Critical Review. The International Journal of Research into Island Cultures. 5(2), 45-67.

Thompson, M., Ellis, R. \& Wildavsky, A. (1990). Cultural Theory. Boulder: Westview Press.

Trablesi, M. (2005). L'insularité. Limoges : Presses Universitaires Blaise Pascal.

UN (2012). Maldives, Map No. 4479, 2012. Retrieved from http://www.un.org/Depts/Cartographic/

UNDP (2010a). Assessment of Development Results. Evaluation of UNDP Contribution. New York: UNDP.

UNDP (2010b). Integrating Climate Change Risk Into Resilient Island Planning in the Maldives. Retrieved from http://www.environment.gov.mv

van Alphen, K., van Sark, W.G. \& Hekkert M.P. (2007). Renewable energy technologies in the Maldives - determining the potential. Renewable and Sustainable Energy Reviews, 11, 16501674. https://doi.org/10.1016/j.rser.2006.02.001

Vink, M.P.M. (2007). Indian Ocean Studies and the 'new thalassology'. Journal of Global History, 2, 41-62. https://doi.org/10.1017/S1740022807002033

Water Solutions, (2016). Maps of the Maldives. The Complete Guide to the Atolls \& Islands of the Maldives. Malé: Water Solutions Pvt. Ltd.

Yamamoto, L., \& Esteban, M. (2010). Vanishing Islands States and sovereignty. Ocean \& Coastal Management, 53, 1-9. https://doi.org/10.1016/j.ocecoaman.2009.10.003 